\title{
Challenges regarding potable water supply management by South African municipalities
}

\author{
E. J. Nealer ${ }^{1} \&$ E. S. Van Eeden ${ }^{2}$ \\ ${ }^{1}$ School of Social and Government Studies, \\ North-West University, South Africa \\ ${ }^{2}$ School for Basic Sciences, North-West University, South Africa
}

\begin{abstract}
Local government in South Africa (SA) has come a long way from the period when there were over 800 racially segregated municipalities scattered all over the country. Since the new Constitution took effect in October 1996 and the Local Government: Municipal Demarcation Act was promulgated in July 1998, the municipalities have been merged into currently 284 municipalities which now cover the country in a 'wall-to-wall' manner, and are focused on the provision of an increased number of diverse and complex basic municipal services to geographical areas and citizens that were maybe previously neglected. To achieve the last-mentioned, the municipalities' outer boundaries have been re-demarcated, newly merged municipalities with new organisational structures and policies have been established and transformed organisational arrangements have been incorporated for more accessible and transparent citizen participation (Craythorne, D.L. 2006. Municipal administration: The handbook. Cape Town: Juta. p. 51-54).

This paper highlights the nature and extent of a transformed local government sphere in South Africa, some important legislation, and some relevant challenges regarding water affairs and municipal governance. Hopefully this research will contribute to the cultivation of an environment conducive to consolidating local governance and water management knowledge creation in the local government sphere of SA.

Keywords: municipality, diversity and complexity, environmental management, potable water, hydrological and hydro-geological information, water supply management, water supply related legislation.
\end{abstract}




\section{Introduction}

Local government in South Africa (SA) has come a long way from the period when there were over 800 racially segregated local government sphere institutions consisting of municipalities, town councils, town boards, divisional councils, village management boards, health committees etc. scattered all over the country with large peri-urban and rural areas falling in regions where there was no municipal service rendering. This was a local government result brought about by the previous National Party government's apartheid policy. The nature and extent of the previously disadvantaged local governance underwent a serious transformation after the African National Congress (ANC) won the country's first democratic election in April 1994.

The Constitution of the Republic of South Africa Act 108 of 1996 (the Constitution) led the way for a flood of new and transformed legislation in the developing South Africa. For the first time the place and role of local government were identified and taken up in legislation. The Constitution establishes three categories of municipality, namely:

- Category A Metropolitan municipality that has exclusive municipal executive and legislative authority in its geographically demarcated area;

- Category B Local municipality that shares executive and legislative authority in its geographically demarcated area with the Category C District municipality within whose municipal area it falls; and

- Category C District municipality that has municipal executive and legislative authority in an area that includes more than one Category B Local municipality.

The subsequent Local Government: Municipal Demarcation Act 27 of 1998 established 284 municipalities which now cover the country in a 'wall-to-wall' manner, and are focused on growing local economies and maintaining the provision of an increased number of diverse and more complex basic municipal services to geographical areas and citizens that were previously neglected (see Fig 1 hereunder).

The newly established and merged municipalities are demarcated according to aspects such as interdependence, capacity, existing boundaries, land use, administrative consequences and the topographical, environmental and physical characteristics of an area. Unfortunately the last mentioned factor did not specifically take into consideration aspects such as overall geology (e.g. sensitive karst [dolomite] areas with hydro-geologically unconfined groundwater aquifers) and surface water catchment (river basin) areas.

This transformed local government environment has brought about many changes in the nature and extent of basic public services delivered at the grassroots level of a developing country with limited resources and unlimited needs especially in the area of potable water supply services.

This paper will firstly highlight the changed environmental context of public service delivery in the local government sphere of the country. Then the focus will shift in greater detail to the nature and extent of current realities of local governance, dynamics and challenges regarding a basic public service such as 
potable water supply management by municipalities. Hopefully this research will contribute to the cultivation of an environment conducive to consolidating local governance and water management knowledge creation in the local government sphere of a developing city.

\section{Orientation}

In the quest for more knowledge and insight into the municipal governance of a semi-arid and developing South African environment after 1994, the place and role of potable water supply may be regarded as of primary importance.

To ensure an improvement in the effective and efficient delivery of basic public services such as potable water supply especially in the developing local government sphere of SA, the government-of-the-day will have to take note of the most urgent challenges and address them in a more coordinated, pro-active and macro goal-orientated manner. Government, together with its citizens, should know and understand that, as inhabitants of a semi-arid country, serious consideration must be given to the statement below made by James Clarke as far back as 1991:

'Seventy one per cent of the Earth's surface is covered in water. While ninety eight per cent thereof is undrinkable sea water, only 1,2 per cent constitutes fresh water, which is locked in the polar caps and in glaciers. Consequently, inhabitants have a mere 0,8 per cent to inter alia, drink, irrigate their crops, manufacture steel, cool power stations, bath and transport sewage' [2].

To understand this situation also requires more knowledge on the nature and extent of the so-called hydrological water cycle from rainfall to water runoff. It is a complex system where several processes (infiltration of water, surface water runoff, recharge of groundwater aquifers, seepage, re-infiltration of water, and moisture recycling) are interconnected and interdependent with only one direction of flow: downstream [3]. This becomes more essential if municipalities are geologically underlain by Karst (dolomite) bedrock. In this type of natural environment the effective management of water resources must be achieved according to specific scientifically established hydro-geological protocols to prevent the forming of ground-surface cracks, ponors (shallow ground surface subsidence) and sinkholes. Unfortunately a large number of the municipalities of South Africa are situated in such areas (see Fig. 1 hereunder).

\section{Historical overview of legislative transformation}

The Constitution arranges the so-called 'social contract' between the South African Government and the citizens of the country by the structuring of the three spheres of governmental legislature, judiciary and execution of public policies. The new ANC-led government accepted a constitution in which it is under a moral obligation to be sensitive to, identify, and seriously take notice of the unlimited needs of the country's citizens and then by means of effective prioritization, determine which of them should be addressed through effective and efficient public administration and management in an attempt to add value in 


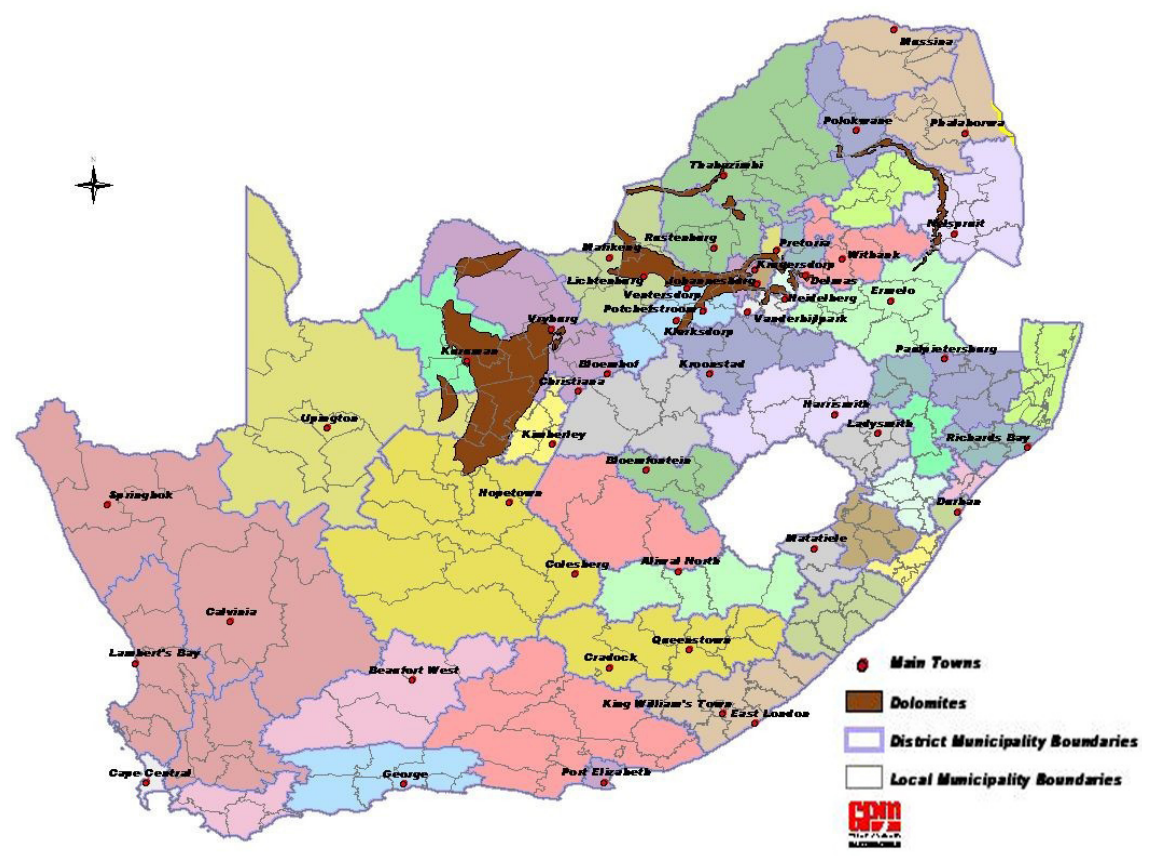

Figure 1: Topographical map of the wall-to-wall Municipalities and the Karst areas in South Africa. (Source [4].)

the respective communities and the country's society as a whole. It immediately emphasised that its Reconstruction and Development Programme (RDP), as part of its political manifesto and foundation of all its new public policies, would be implemented and every effort be made to improve public service delivery in all three spheres of government. One of the four pillars of the RDP is 'meeting basic needs' of which access to basic water supply and sanitation services for all citizens of South Africa was made a priority [5]. Consequently, the former Minister of the Department of Water Affairs and Forestry (DWAF) (Prof Kader Asmal), during May 1994, initiated a process to review all water-related legislation [6]. The overall objective of this process was to change the South African water dispensation so that socio-economic demands and environmental management requirements would be met in as effective, efficient and economical manner as possible, and equal access for all South Africans would be provided [7]. See Table 1 for some examples of transformed government policies and legislation (in date sequence) in the water affairs and municipal environment of the country.

From Table 1 one can distinguish that the change in government in South Africa since April 1994 has produced an overall revisit and transformation of existing executive public policies in furthering the developmental environment of the country as a whole. So for example, the Constitution brought about a restructuring of public sector institutions with transformed strategies and goals. 
Table 1: Important examples of legislation in SA since April 1994 as related to water and municipal governance.

\begin{tabular}{|c|c|c|}
\hline Year: & Act: & Summarised purpose and / or goal: \\
\hline $\begin{array}{l}1994 \\
\text { (Nov.) }\end{array}$ & $\begin{array}{l}\text { White Paper on } \\
\text { Water Supply } \\
\text { and Sanitation } \\
\text { Policy. }\end{array}$ & $\begin{array}{l}\text { This document is dedicated to the millions of } \\
\text { SA's citizens who struggle daily with the } \\
\text { burden of not having the most basic of services } \\
\text { [8]. }\end{array}$ \\
\hline $\begin{array}{l}1995 \\
\text { (Nov.) }\end{array}$ & $\begin{array}{l}\text { White Paper on } \\
\text { the } \\
\text { Transformation } \\
\text { of Public } \\
\text { Service. }\end{array}$ & $\begin{array}{l}\text { To establish a policy framework to guide the } \\
\text { introduction and implementation of new } \\
\text { policies and legislation aimed at transforming } \\
\text { the South African public service [9]. }\end{array}$ \\
\hline $\begin{array}{l}1996 \\
\text { (Oct.) }\end{array}$ & $\begin{array}{l}\text { Constitution of } \\
\text { the Republic of } \\
\text { South Africa Act } \\
108 \text { of } 1996 \text {. }\end{array}$ & $\begin{array}{l}\text { This is the supreme law of the Republic, which } \\
\text { embraces the human rights principles and sets } \\
\text { forth the right of access to water as part of a } \\
\text { lengthy list of social and economic rights [10]. }\end{array}$ \\
\hline $\begin{array}{l}1997 \\
\text { (Oct.) }\end{array}$ & $\begin{array}{l}\text { White Paper on } \\
\text { Transforming } \\
\text { Public Service } \\
\text { Delivery (Batho } \\
\text { Pele [people } \\
\text { first] White } \\
\text { Paper). }\end{array}$ & $\begin{array}{l}\text { This seeks to introduce a fresh approach to } \\
\text { service delivery: an approach which puts } \\
\text { pressure on systems, procedures, attitudes and } \\
\text { behaviour within the Public Service and } \\
\text { reorients them in the customer's favour, an } \\
\text { approach which puts the people first [11]. }\end{array}$ \\
\hline $\begin{array}{l}1997 \\
\text { (Dec.) }\end{array}$ & $\begin{array}{l}\text { Water Services } \\
\text { Act } 108 \text { of } 1997 .\end{array}$ & $\begin{array}{l}\text { To provide for, inter alia, the rights of access to } \\
\text { basic water supply and basic sanitation, the } \\
\text { setting of national standards and of norms and } \\
\text { standards for tariffs, water services } \\
\text { development plans, establishment of water } \\
\text { boards, monitoring of water services, and } \\
\text { financial assistance to water services } \\
\text { institutions [12]. }\end{array}$ \\
\hline $\begin{array}{l}1998 \\
\text { (Jul.) }\end{array}$ & $\begin{array}{l}\text { Local } \\
\text { Government: } \\
\text { Municipal } \\
\text { Demarcation Act } \\
27 \text { of } 1998 \text {. }\end{array}$ & $\begin{array}{l}\text { To provide for criteria and procedures for the } \\
\text { determination of municipal boundaries by an } \\
\text { independent authority [13]. }\end{array}$ \\
\hline $\begin{array}{l}1998 \\
\text { (Aug.) }\end{array}$ & $\begin{array}{l}\text { National Water } \\
\text { Act } 36 \text { of } 1998 .\end{array}$ & $\begin{array}{l}\text { To recognise that water in SA is a scarce and } \\
\text { unevenly distributed national resource which } \\
\text { belongs to all its inhabitants and that the } \\
\text { National Government is responsible for the } \\
\text { nation's water resources and their use. This } \\
\text { should be attained in a sustainable manner by } \\
\text { means of, inter alia, integrated water catchment } \\
\text { management of all aspects of water resources } \\
\text { and, where appropriate, the delegation of }\end{array}$ \\
\hline
\end{tabular}


Table 1: $\quad$ Continued.

\begin{tabular}{|c|c|c|}
\hline Year: & Act: & Summarised purpose and / or goal: \\
\hline & & $\begin{array}{l}\text { management functions to a regional or } \\
\text { catchment level so as to enable everyone to } \\
\text { participate [14]. }\end{array}$ \\
\hline $\begin{array}{l}1998 \\
\text { (Nov.) }\end{array}$ & $\begin{array}{l}\text { National } \\
\text { Environmental } \\
\text { Management Act } \\
107 \text { of } 1998 .\end{array}$ & $\begin{array}{l}\text { To provide for co-operative, environmental } \\
\text { governance by establishing principles for } \\
\text { decision-making on matters affecting the } \\
\text { environment, institutions that will promote co- } \\
\text { operative governance and procedures for } \\
\text { coordinating environmental functions exercised } \\
\text { by organs of state [15]. }\end{array}$ \\
\hline $\begin{array}{l}1998 \\
\text { (Dec.) }\end{array}$ & $\begin{array}{l}\text { Local } \\
\text { Government: } \\
\text { Municipal } \\
\text { Structures Act } \\
117 \text { of } 1998 .\end{array}$ & $\begin{array}{l}\text { To provide for the definition and establishment } \\
\text { of municipalities in accordance with the } \\
\text { requirements relating to categories and types of } \\
\text { municipalities and provide for an appropriate } \\
\text { division of functions and powers between the } \\
\text { categories of municipalities [16]. }\end{array}$ \\
\hline $\begin{array}{l}2000 \\
\text { (Nov.) }\end{array}$ & $\begin{array}{l}\text { Local } \\
\text { Government: } \\
\text { Municipal } \\
\text { Systems Act } 32 \\
\text { of } 2000 \text {. }\end{array}$ & $\begin{array}{l}\text { To enable municipalities to move progressively } \\
\text { towards the social and economic upliftment of } \\
\text { local communities, and ensure universal access } \\
\text { to essential services that are affordable to all } \\
\text { [17]. }\end{array}$ \\
\hline $\begin{array}{l}2004 \\
\text { (Feb.) }\end{array}$ & $\begin{array}{l}\text { Local } \\
\text { Government: } \\
\text { Municipal } \\
\text { Finance } \\
\text { Management Act } \\
56 \text { of } 2003 \text {. }\end{array}$ & $\begin{array}{l}\text { To secure sound and sustainable management } \\
\text { of the financial affairs of municipalities and } \\
\text { other institutions in the local sphere of } \\
\text { government [18]. }\end{array}$ \\
\hline
\end{tabular}

This subsequently led to the revisiting of executive policies such as the Batho Pele (people first) and RDP. With reference to the new government's quest to improve the public management of water affairs, the Water Act was promulgated to for the first time in the country's history bring about integrated water resources management according to the surface water drainage regions for the benefit of all its citizens. The need then arose to identify and regulate the place and role of a more effective, representative and development orientated local government sphere through for example the Local Government: Municipal Systems Act of November 2000.

\section{Nature and extent of local governance}

In line with the transformation of legislation, the local government sphere elections on 5 December 2000 ushered in a new system of local governance in South Africa. The newly structured and empowered local government sphere has 
been granted some degree of autonomy and expanded responsibilities (a shift to developmental local government) [19]. Prior to that date the municipalities were characterised by racial segregation, unequal allocation of resources and unequal delivery of basic public services.

The legal and administrative structures inherited by the current Government did not serve the broad population of all the municipalities. Public participation now a constitutional requirement - was non-existent [20]. Consequently, all decision-making related to public service delivery was undertaken on behalf of the majority. In order to ensure that truly integrated economic development and improved basic public services are delivered effectively and efficiently to the under-serviced communities, the municipal boundaries have been re-demarcated, newly merged municipalities with new organisational structures and policies have been formed and transformed organisational arrangements incorporated for more accessible and transparent citizen participation [21].

The transformed municipal management of potable water supply now entails the execution of highly complex hydrological, hydro-geological and public management functions in a very dynamic and highly regulated environment. In addition, the nature and impact of the physical environment are also difficult to manage. It, therefore, requires the municipal managers, leading officials as well as the committed political office-bearers of a municipality to be equipped with specific knowledge and information regarding the physical environment and to, for example, utilise geographical mapping tools in order to improve their longterm planning skills. Some advantages, challenges and possible recommendations for improvement of local governance will now be identified.

\subsection{Advantages}

The ANC-led government's attempts to fulfil their side of the 'social contract' regarding more effective, efficient, economical, equal and sustainable public service delivery are for example simplified by the following:

- The newly merged 284 municipalities of the country, are now focused on growing local economies and maintaining the provision of a bigger range of more diverse and complex basic municipal services to geographical areas and citizens that were previously neglected;

- DWAF's National Water Act 36 of 1998 now makes provision for holistic and integrated water management according to surface water drainage regions; and

- the natural resources of the country are now managed for the benefit of all the citizens.

\subsection{Challenges}

Unfortunately the new developing South Africa and its public service rendering government institutions are confronted by, amongst other challenges, the following drawbacks: 
- $\quad$ SA is geographically a large semi-arid country with vast open spaces and scarcely habitable rural areas;

- with the current urbanisation level of $56 \%$ in the country [22], the newly established municipalities have much bigger geographical municipal areas and more residents to service and manage;

- the delivery of municipal services to a much bigger group of clients over longer distances is also characterised by a very high level of diversity (different types of functions) and complexity (different levels of skills and execution involved). Furthermore, the 'brain drain' of experienced and skilled municipal officials has resulted in increased work pressure for the municipal managers, officials and political office-bearers;

- the legal and administrative structures inherited by the current Government did not serve the broad population of all the municipalities;

- there has been a lack of attention to maintenance and sustainability of water management infrastructure with resulting high rates of water loss per capita due to internal leakages in houses and deterioration of the reticulation pipeline infrastructure;

- there has been a lack of effective municipal planning (Integrated Development Planning [IDPs] and budgets) which includes aspects such as conducting municipal surveys and profiles of privately owned land and budgets in the restructuring, expansion and maintenance of local government infrastructure [23];

- the fact that the demarcated geographical jurisdictions of municipalities usually do not concur with the identified surface water (rivers) drainage regions prevents holistic and integrated water resources management;

- there is a tendency among community members not to be interested in the origin and management of their potable water as well as the destiny and management of their waste water and sewage; and

- inaccurate and outdated population censuses can influence effective planning in a negative way.

\subsection{Recommendations for improvement}

With these characteristics of the South African local government sphere in mind, the following aspects are identified to ensure an improvement of public service delivery in the country:

- Identify, survey, map, demarcate and inform about the nature and extent of a water drainage region with its rivers, marshes, fountains, groundwater, number of water users and consumers, quantity and quality of water and implement the well-defined, planned and orchestrated holistic management of the region;

- $\quad$ assist in the obtaining and supply of hydrological and logistical knowledge, skills and infrastructure to more correctly manage the identification, surveying, development, transport, storage, treatment, distribution, administering of tariffs, collection, storage and treatment of used and storm 
water and in the last instance return the treated used water (effluent) into the surface water catchment for use by downstream inhabitants;

- the conjunctive use of both surface (rivers) and underground (boreholes) water should be investigated and implemented by municipalities. Groundwater which is less exposed to evaporation, is often of better quality (naturally pre-filtered) and provides a slow release of water to a cyclical surface water supply [24];

- encourage administrative and political willingness to put party-politics and overemphasised 'red tape' aside (even only for a few years) and to look, listen and learn in all earnest to bring about effective transformation and improvement in local governance and basic public service delivery towards economic growth, development and prosperity; and

- the public service delivery infrastructure of a municipality should be maintained, developed, expanded, constructed and managed in a proactive, effective, efficient and economical way.

\section{Conclusion}

The place and role of the local government sphere in South Africa have now been demarcated, the necessary legislation and structures are in place, and the governmental public service providers must 'just get their act together' and start to implement and execute the numerous governmental policies on the more effective and efficient rendering of public services to the citizens of the country. They have worked hard at creating democratic and accountable government by overhauling the local governance model that existed before 2000 .

Unfortunately the committed municipalities are continually experiencing new pressures to deliver a wider variety of usually more complex basic urban public services to citizens who are developing new and more sophisticated needs. This quest to deliver public services in a more effective, efficient, equal, economic and sustainable manner now requires an optimum level of cooperation and integration between the role-players and stakeholders involved. Together, these actors will be able to bring about a positive difference in the nature of basic public service delivery and development in the very dynamic and highly politicised local government sphere.

\section{References}

[1] Craythorne, D.L. 2006. Municipal administration: The handbook. Cape Town: Juta. p. 51-54.

[2] Clarke, J. 1991. Back to Earth: South Africa's environmental challenges. Halfway House: Southern Book Publishers. page 79.

[3] IUCN. 2005. Water demand management. Pretoria: IUCN. p. 22.

[4] GPM Consultants. 2009. Topographical map of the wall-to-wall Municipalities and the Karst areas in South Africa. Polokwane. 
[5] Department of Water Affairs and Forestry (DWAF). 2004. "A history of the first decade of Water Service delivery in South Africa 1994 to 2004”. Pretoria: DWAF. p. 4.

[6] Gildenhuys, A. 1999. “A new water dispensation”. Butterworths Property Law Digest (Vol. 3, Part 1) p. 10.

[7] Pienaar, G. J. \& Van der Schyff, E. (in JWN Tempelhoff). 2005. African water histories: Transdisciplinary discourses. Vanderbijlpark: Creda Printers. p. 263.

[8] Republic of South Africa. 1994. White Paper on Water Supply and Sanitation Policy. Pretoria: Government Printer.

[9] Republic of South Africa. 1995. White Paper on the Transformation of Public Service. Pretoria: Government Printer.

[10] Republic of South Africa. 1996. Constitution of the Republic of South Africa Act 108 of 1996. Pretoria: Government Printer

[11] Republic of South Africa. 1997(a). White Paper on Transforming Public Service Delivery. Pretoria: Government Printer.

[12] Republic of South Africa. 1997(b). Water Services Act 18 of 1997. Pretoria: Government Printer.

[13] Republic of South Africa. 1998(a). Local Government: Municipal Demarcation Act 27 of 1998. Pretoria: Government Printer.

[14] Republic of South Africa. 1998 (b). National Water Act 36 of 1998. Pretoria: Government Printer.

[15] Republic of South Africa. 1998 (c). National Environmental Management Act 107 of 1998. Pretoria: Government Printer.

[16] Republic of South Africa. 1998(d). Local Government: Municipal Structures Act 117 of 1998. Pretoria: Government Printer.

[17] Republic of South Africa. 2000. Local Government: Municipal Systems Act 32 of 2000. Pretoria: Government Printer.

[18] Republic of South Africa. 2003. Local Government: Municipal Finance Management Act 56 of 2003. Pretoria: Government Printer.

[19] Fast, H. \& Engelbrecht, B. 1999. Local Government Transformation: A guide for health workers in Kwik-Skwiz 18, April 1999, p. 2.

[20] Motshekga, M. 2008. Lessons to be learned from the $19^{\text {th }}$ century on governance, which could enhance our current leadership in the development of local government sector (Paper delivered, Local Government SETA, Boksburg, March 2008), p. 1.

[21] Craythorne, D.L. 2006. Municipal administration: The handbook. Cape Town: Juta. p.51-54.

[22] South African cities network. 2006. State of the cities report 2006. SACN. p. $2: 17$.

[23] CSIR. 2007. The state of municipal infrastructure in South Africa and its operation and maintenance: An overview. Pretoria: CSIR.

[24] Department of Water Affairs and Forestry (DWAF). 2006. Guidelines for Water Supply Systems Operation and Management Plans During Normal and Drought Conditions. Pretoria: DWAF. 